University of Wollongong

Research Online

Faculty of Science - Papers (Archive)

Faculty of Science, Medicine and Health

$1-1-2012$

\title{
DGT-induced copper flux predicts bioaccumulation and toxicity to bivalves in sediments with varying properties
}

\author{
Stuart L. Simpson \\ CSIRO, stuart.simpson@csiro.au \\ Heloise Yverneau \\ CSIRO \& National Graduate School of Chemistry of Montpellier \\ Anne Cremazy \\ University de Bordeaux, France \\ Chad V. Jarolimek \\ CSIRO Land and Water \\ Helen Price \\ University of Wollongong, hlp995@uow.edu.au
}

See next page for additional authors

Follow this and additional works at: https://ro.uow.edu.au/scipapers

Part of the Life Sciences Commons, Physical Sciences and Mathematics Commons, and the Social and Behavioral Sciences Commons

\section{Recommended Citation}

Simpson, Stuart L.; Yverneau, Heloise; Cremazy, Anne; Jarolimek, Chad V.; Price, Helen; and Jolley, Dianne F.: DGT-induced copper flux predicts bioaccumulation and toxicity to bivalves in sediments with varying properties 2012, 9038-9046.

https://ro.uow.edu.au/scipapers/4336

Research Online is the open access institutional repository for the University of Wollongong. For further information contact the UOW Library: research-pubs@uow.edu.au 


\title{
DGT-induced copper flux predicts bioaccumulation and toxicity to bivalves in sediments with varying properties
}

\begin{abstract}
Many regulatory frameworks for sediment quality assessment include consideration of contaminant bioavailability. However, the "snap-shots" of metal bioavailability provided by analyses of porewaters or acid-volatile sulfidesimultaneously extractable metal (AVS-SEM) relationships do not always contribute sufficient information. The use of inappropriate or inadequate information for assessing metal bioavailability in sediments may result in incorrect assessment decisions. The technique of diffusive gradients in thin films (DGT) enables the in situ measurement of metal concentrations in waters and fluxes from sediment porewaters. We utilized the DGT technique to interpret the bioavailability of copper to the benthic bivalve Tellina deltoidalis in sediments of varying properties contaminated with copperbased antifouling paint particles. For a concentration series of copper-paint contaminated sandy, siltysand, and silty sediment types, DGTprobes were used to measure copper fluxes to the overlying water, at the sedimentwater interface, and in deeper sediments. The overlying water copper concentrations and DGT-Cu fluxes were shown to provide excellent exposure concentration-response relationships in relation to lethal effects occurring to the copper-sensitive benthic bivalve, T. deltoidalis. The study demonstrates the strength of the DGT technique, which we expect will become frequently used for assessing metal bioavailability in sediments.
\end{abstract}

\section{Keywords}

induced, copper, flux, predicts, dgt, properties, sediments, varying, bioaccumulation, toxicity, bivalves, CMMB

\section{Disciplines}

Life Sciences | Physical Sciences and Mathematics | Social and Behavioral Sciences

\section{Publication Details}

Simpson, S. L., Yverneau, H., Cremazy, A., Jarolimek, C. V., Price, H., Jolley, D. F. (2012). DGT-induced copper flux predicts bioaccumulation and toxicity to bivalves in sediments with varying properties. Environmental Science and Technology (Washington), 46 (16), 9038-9046.

\section{Authors}

Stuart L. Simpson, Heloise Yverneau, Anne Cremazy, Chad V. Jarolimek, Helen Price, and Dianne F. Jolley 
Simpson, Stuart L. ${ }^{\dagger}$, Yverneau, Héloïse, ${ }^{\dagger} ¥$, Cremazy, Anne, ${ }^{\dagger} \S$,

7 Jarolimek, Chad V. ${ }^{\dagger}$, Price, Helen L. ${ }^{\ddagger}$ Jolley, Dianne F.",

$\dagger$ Centre for Environmental Contaminants Research, CSIRO Land and Water, Locked Bag 10 2007, Kirrawee, NSW 2234, Australia

$¥$ Ecole Nationale Supérieure de Chimie de Montpellier - National Graduate School of

$\S$ Université de Bordeaux 1, 33600 Pessac, France.

16

$17 \$$ School of Chemistry, University of Wollongong, NSW 2522, Australia

* To whom correspondence may be addressed (stuart.simpson@csiro.au)

21 Centre for Environmental Contaminants Research, CSIRO Land and Water,

Locked Bag 2007, Kirrawee, NSW 2234, Australia 
ABSTRACT: Many regulatory frameworks for sediment quality assessment include consideration of contaminant bioavailability. However, the 'snap-shots' of metal bioavailability provided by analyses of pore waters or acid-volatile sulfide - simultaneously extractable metal (AVS-SEM) relationships do not always contribute sufficient information. The use of inappropriate or inadequate information for assessing metal bioavailability in sediments may result in incorrect assessment decisions. The technique of diffusive gradients in thin films (DGT) enables the in situ measurement of metal concentrations in waters and fluxes from sediment pore waters. We utilised the DGT technique to interpret the bioavailability of copper to the benthic bivalve Tellina deltoidalis in sediments of varying properties contaminated with copper-based antifouling paint particles. For a concentration series of copper-paint contaminated sandy, silty-sand and silty sediment types, DGT-probes were used to measure copper fluxes to the overlying water, at the sediment-water interface and in deeper sediments. The overlying water copper concentrations and DGT-Cu fluxes were shown to provide excellent exposure concentration-response relationships in relation to lethal effects occurring to the copper-sensitive benthic bivalve, T. deltoidalis. The study demonstrates the strength of the DGT technique, which we expect will become frequently used for assessing metal bioavailability in sediments.

Keywords: DGT, copper, antifouling paint, sediment, bivalve, bioaccumulation, ecotoxicology. 


\section{Introduction}

The technique of diffusive gradients in thin films (DGT) was developed to enable the in situ measurement of metal concentrations in waters ${ }^{1}$ and fluxes from sediment pore waters. ${ }^{1,2}$ In a DGT device, dissolved metal species diffuse through a polyacrylamide gel layer and become trapped in a gel impregnated with a metal-exchange resin, which acts as a metal sink. ${ }^{3}$ The removal of metals from sediment porewaters causes the concentration to decline immediately adjacent to the device. This localised decline could disturb the dynamic equilibrium between the sediment and metal in solution and induced release of metals to solution ${ }^{4}$, the extent of which will depend on the rate of metal resupply from the sediment solid phase to the porewater. If there is rapid resupply, metal concentrations in pore waters may be calculated from the DGT-accumulated metal concentration. However, when resupply from the sediments is limited the DGT-flux provides information on the relative rate of remobilisation of metals from sediments to the pore water. ${ }^{5}$ Hence the DGT directly measures the flux of metal from the sediment during the deployment time, which reflects the concentration in the porewater, its diffusional transport and the supply from the solid phase to solution. ${ }^{6}$ It can be interpreted simply as the average porewater concentration at the interface of the device over the deployment period. The ability of DGT measurements to provide information on the localised remobilisation of metals has been utilised to create high resolution depth profiles of metals within sediments. ${ }^{2,7}$ Such studies have demonstrated the heterogeneity of sediment environments; including the existence of microniches and to characterise zones of metal remobilisation. ${ }^{8-10}$

Existing methods for estimating the bioavailability of metals in sediments to benthic organisms have numerous limitations. ${ }^{11,12}$ For example, the usefulness of chemical extractions that provide information on metal lability varies between metals and the degree of contamination and for the organism being studied. ${ }^{13,14}$ Further to this, the equilibrium partitioning relationships between metals and acid-volatile sulfide (AVS) become less appropriate for organisms that create oxic/sub-oxic micro-environments at burrow walls within sulfidic sediments ${ }^{15,17}$, and pore water analyses provide non time-integrated 'snapshots' of concentrations that change rapidly upon sediment disturbance. ${ }^{18,19}$

The DGT-accumulated metal concentration has been determined to consist of free metal ions, metal ions present as simple inorganic complexes, and labile organic complexes. ${ }^{20,21}$ As these metal fractions represent the most bioavailable metals ${ }^{20-22}$, the time-integrated measure of the bioavailable metal provided by the DGT technique is proving to be a powerful tool for 
benthic organisms is influenced by the characteristics of the metal, the properties of the sediments and the varying exposure pathways of the organisms. ${ }^{25-28}$ The DGT technique was used by Wegener et al. ${ }^{29}$ to demonstrate that sediment bioturbation and feeding by the oligochate Tubifex modified porewater metal concentrations within surface sediments. The release of metals from sediment particles to pore water will be more rapid for sediments that contain reactive forms of metals when compared to sediments that contain more inert forms of metals, hence differences in DGT-induced metal fluxes are expected to provide a useful measure of the bioavailability of the metals in sediments. Roulier et al..$^{30}$ observed total and DGT-accumulated metal concentrations both provided strong relationships with $\mathrm{Cu}$ and $\mathrm{Pb}$ bioaccumulation from sediments by Chironomus riparius, however, only the DGT technique provided an explanation of different organismal uptake for sediments with similar total metal concentrations.

In the present study we utilise the DGT technique to interpret the bioavailability of copper to the benthic bivalve Tellina deltoidalis in sediments contaminated with copper-based antifouling paint. Copper-based paints are increasingly used by marine industries to reduce biofouling and the abrasion of paint from structures can result in considerable copper concentrations in sediments. ${ }^{31}$ Concentration series of copper-paint contamination were prepared for three sediments, representing sandy, silty-sand and silty environments. DGTinduced copper fluxes were measured in the overlying water, at the sediment-water interface (SWI) and in deeper sediments. The DGT- induced copper flux at the SWI was compared with copper bioaccumulation and toxicity to the bivalve.

\section{Material and Methods}

General methods. All glass and plastic-ware for analyses were usually new and were cleaned by soaking in $10 \%(\mathrm{v} / \mathrm{v}) \mathrm{HNO}_{3}(\mathrm{BDH}$, Analytical Reagent grade) for a minimum of $24 \mathrm{~h}$, followed by thorough rinsing with deionized water (Milli-Q, $18 \mathrm{M} \Omega / \mathrm{cm}$ ). All chemicals were analytical reagent grade or equivalent analytical purity. Water $\mathrm{pH}$, salinity, temperature and dissolved oxygen measurements were made with probes calibrated according to manufacturer instructions (WTW). Methods for sediment particle size (by wet sieving through $63 \mu \mathrm{m}$ nylon sieves followed by gravimetry), total organic carbon (TOC, by high temperature TOC analyzer), porewater (PW) extraction (centrifugation at $800 \mathrm{~g}$ for $5 \mathrm{~min}$ ), and dissolved ammonia analyses are described in Spadaro et al. ${ }^{32}$. Methods for analyses of total recoverable metals (TRM, by microwave assisted aqua reqia), dilute acid extractable metals (AEM, $1 \mathrm{M} \mathrm{HCl}$ ) and acid-volatile sulfide (AVS) (all determined on sub-samples of the same homogenised sediment) are described previously. ${ }^{33}$ Biota tissues were freeze-dried 
before microwave-assisted (MARS 5, CEM) acid/peroxide extraction $\left(3: 1 \mathrm{HNO}_{3}: \mathrm{H}_{2} \mathrm{O}_{2}, 80{ }^{\circ} \mathrm{C}\right.$ for $50 \mathrm{~min}$ ). Dissolved metal concentrations in acid-digests of water, biota and sediment samples were determined by inductively coupled plasma - optical emission spectrometry (ICP-OES, Varian 730-ES) as described in Simpson et al. ${ }^{34}$ The metal concentrations of the acid-digests of DGT gels were determined by inductively coupled plasma-mass spectrophotometry (ICP-MS, Agilent 7500ce). As part of the quality assurance, analyses of filter and acid-digest blanks, replicates for $20 \%$ of samples, analyte sample-spikes and the certified reference materials (CRMs) were performed. Replicates were within 20\% and recoveries for spikes and CRMs, PACS-2 for sediment (National Research Council Canada, NRCC) and DORM-3 for biota (fish protein, NRCC), were within 85-115\% of expected values. The limits of reporting for the various methods were less than $10 \%$ of the lowest measured values.

Test media and organisms. Clean seawater was collected from Port Hacking, Sydney, Australia, membrane filtered $(0.45 \mu \mathrm{m})$, and acclimated to a room temperature of $21 \pm 1^{\circ} \mathrm{C}$. Where necessary, the salinity of the filtered seawater was adjusted to the test salinity of 30 PSU using Milli-Q water. Surface sediments (0-3 cm depth) were collected from three intertidal estuarine locations for use as controls and for preparing sediment with a range of particles sizes as described in Strom et al. ${ }^{35}$ Three sediments were prepared with $10 \%$ (sandy), 30\% (silty-sand) and 60\% (silty) $<63 \mu \mathrm{m}$ particles, respectively. T. deltoidalis with shell lengths of 5-12 mm were collected from Lane Cove River (NSW, Australia) and maintained as described previously. ${ }^{36,37}$

Copper-based paint spiked sediments. Copper-based antifouling paint (13\% copper(I) oxide $/ 4 \%$ zinc oxide; Hempanet, Hempel) was dried at $45^{\circ} \mathrm{C}$ for $24 \mathrm{~h}$, snap-frozen in liquid nitrogen, crushed using a Teflon beaker and mortar, and the $<180 \mu \mathrm{m}$ particles isolated using a nylon sieve. Before TRM analyses, the paint samples were heated in a porcelain crucible at $500^{\circ} \mathrm{C}$ for $4 \mathrm{~h}$ to destroy the organic matrix. Copper concentration series of paint-spiked sediments were prepared by adding the required amounts of paint to the three sediments. The sediments remained at $\mathrm{pH} 7.7 \pm 0.2$ without $\mathrm{pH}$-adjustment and were mixed and equilibrated for a period of 30 days ${ }^{38}$ Copper concentrations are frequently $100-1000 \mathrm{mg} / \mathrm{kg}$ in sediments near marinas and aquaculture leases that use copper-based paints on boats, nets and other marine structures. ${ }^{31,39}$ An initial concentration series of 0,200 and $1000 \mathrm{mg} \mathrm{Cu} / \mathrm{kg}$ was prepared and tested. After 8 months (stored refrigerated) the $1000 \mathrm{mg} \mathrm{Cu} / \mathrm{kg}$ sediment from each particle size composition, was diluted with control sediment of the same composition to create sandy sediments with $0,50,100$, and $200 \mathrm{mg} \mathrm{Cu} / \mathrm{kg}$, and silty-sand and silty sediments 
with $0,100,200$, and $400 \mathrm{mg} \mathrm{Cu} / \mathrm{kg}$. These dilution series were mixed and equilibrated for a further 30 days to achieve dissolved-particulate copper partitioning similar to that occurring in field-contaminated sediments. ${ }^{40}$ At the completion of the equilibration process, sub-samples of the copper-paint spiked sediments taken for duplicate analyses of $\mathrm{pH}$, dissolved porewater metals, particulate metals (TRM and AEM), particle size distribution, TOC, and AVS.

Diffusive gradients in thin films (DGT). Plastic DGT assemblies $(24 \times 4 \times 0.5 \mathrm{~cm}$, with $1.8 \times 15 \mathrm{~cm}$ windows) were purchased from DGT Research (http://www.dgtresearch.com/). DGT gels were prepared following the procedures recommended by DGT Research (details are provided in Section S1 of the Supporting Information,). The DGT probe cross-section comprised: backing plate, $0.45 \mu \mathrm{m}$ filter membrane, $0.25 \mathrm{~mm}$ Chelex gel, $0.5 \mathrm{~mm}$ diffusive gel, $0.45 \mu \mathrm{m}$ filter membranes, and a front window plate. All components had been carefully prepared to minimise metal contamination. Deoxygenated DGT probes were gently inserted into the sediments to a depth of $4 \mathrm{~cm}$ with care to ensure a good contact between the sediment and the DGT membrane. Deployments times of $24 \mathrm{~h}$ (DGT equilibration) were selected based on Garmo et al., ${ }^{41}$ as we used $0.5 \mathrm{~mm}$ diffusive gel thickness in environmentally relevant PW-Cu concentrations in the presence of humic acids. After $24 \mathrm{~h}$ of deployment, DGT probes were gently removed from the beakers and position of the sediment-water interface (SWI) and overlying water depth were recorded. The probes were immediately rinsed with Milli-Q water to remove sediment particles, then held in clean plastic bags at $4^{\circ} \mathrm{C}$ until disassembly. DGT devices were disassembled (within 10 days of retrieval) and resin gel slices cut using a Teflon coated blade to obtain the desired vertical profile. For the first DGT deployment there was a $1.5 \mathrm{~cm}$ slice at the SWI (from $-0.75 \mathrm{~cm}$ to $+0.75 \mathrm{~cm}$ ), two $2-\mathrm{cm}$ slices in the overlying water above the SWI-slice and 2-cm slice in the sediment above the SWIslice. For the second DGT deployment there was a $1-\mathrm{cm}$ slice at the SWI $(-0.5 \mathrm{~cm}$ to $0.5 \mathrm{~cm})$, and $1 \mathrm{~cm}$ slices above and below the SWI-slice. The mid-point of the slice was set as the location in data analysis and Figure 1. Slices from below the SWI were washed with Milli-Q water to remove any sediment particles. Each slice was weighed, then eluted with $1 \mathrm{M} \mathrm{HNO}_{3}$ for 16-24 h before analysis by ICP-MS. Undeployed DGT probes were analysed as handling blanks and their copper concentrations were less than $5 \%$ of the lowest measured concentration.

Bivalve bioaccumulation bioassays. The test sediments $(400 \mathrm{~mL})$ and overlying water

183 (500 mL) were added to $1 \mathrm{~L}$ Pyrex beakers (washed sequentially with phosphate-free 184 detergent, $1 \% \mathrm{HNO}_{3}$ and Milli-Q water) five weeks prior to the start of the tests and kept in a temperature controlled lab $\left(21 \pm 3^{\circ} \mathrm{C}\right.$, normal day light conditions $) .{ }^{37}$ The beakers were 
bubbled with air during this period and throughout the tests, and developed stratified redox profiles. $^{42}$ On the day of test commencement the overlying water was removed to a level of 2 $\mathrm{cm}$ above the sediment surface, 10 bivalves were added to each beaker, and then new seawater was added. Water $\mathrm{pH}(\mathrm{pH} 8.2 \pm 2)$, salinity $\left(31 \pm 1 \%\right.$ ), temperature $\left(21 \pm 1^{\circ} \mathrm{C}\right.$, ) and dissolved oxygen concentration ( $>80 \%$ saturation), and water levels were monitored throughout the tests. The overlying water was changed 3 times per week after sub-sampling for analyses of dissolved copper and ammonia. The DGT probes were inserted on days 8 and 15, and removed $24 \mathrm{~h}$ after deployment. The tests were terminated after 30 days and surviving organisms were counted, and allowed to depurate overnight in clean seawater before refrigeration. The bivalve shells were opened using a Teflon coated razor blade and the soft tissue transferred to a pre-weighed $50 \mathrm{~mL}$ polycarbonate vial using plastic tweezers and then frozen at $-20^{\circ} \mathrm{C}$ before analyses.

Statistical analyses. At the end of the bioaccumulation bioassays the percent survival in tests relative to survival in the controls was recorded. All statistical analyses were carried out using the software Toxcal (Version 5.0.23, TidePool Scientific Software). Unless otherwise stated $p=0.05$ was the level of significance. Effect concentration causing $\mathrm{x} \%$ of the lethality to the bivalve $\left(\mathrm{LC}_{\mathrm{x}}\right)$ were estimated from concentration-response data and corresponding copper concentration using linear interpolation as described previously. ${ }^{35,37}$ Correlations (Pearson's product-moment) were performed on the particulate metal concentrations using statistical software (NCSS).

\section{Results and Discussion}

Properties of the paint-spiked sediments. The TRM copper and zinc concentrations in the paint were $9.3 \pm 0.7 \mathrm{mg} / \mathrm{kg}$ and $3.0 \pm 0.2 \%$, respectively. These compared to concentrations of $13 \pm 1 \%$-Cu and $4.0 \pm 1 \%$-Zn, specified by the manufacturer ${ }^{43}$ and were similar to the compositions of most copper-based antifouling formulations. ${ }^{44}$

The properties of the paint-spiked sediments are shown in Table 1. The $\mathrm{pH}$ of the sediments ranged from 7.7-7.9; exhibiting no relationship with spike concentration or sediment type. The sandy, silty-sand and silty sediments had TOC concentrations of $0.7,1.6$, $3.1 \%$, respectively, and particle size distributions within $10 \%$ of the nominal 10, 30 and $60 \%$ $<63 \mu \mathrm{m}$ particles. Less than $4 \%$ of each sediment contained $63-180 \mu \mathrm{m}$ size fraction and the remainder was mostly $180-1100 \mu \mathrm{m}$ sized sand. The AVS concentrations were $<0.5 \mu \mathrm{mol} / \mathrm{g}$ for all the sediments. For total copper concentrations (TR-Cu) were within $25 \%$ of the nominal concentrations. Dilute acid-extractable copper concentrations (AE-Cu) comprised 
$48 \%$ to $94 \%($ mean $\pm \mathrm{SD}=68 \pm 10 \%$ ) of the $\mathrm{TR}-\mathrm{Cu}$, and the copper extractability of the 200 $\mathrm{mg} / \mathrm{kg}$ AE-Cu remained relatively constant over the 8 -months between the $1^{\text {st }}$ and $2^{\text {nd }}$ series. This range of copper extractability was significantly greater than we have found for fieldcollected sediments contaminated with copper-based antifouling paints, where we have measured AE-Cu was $6 \pm 9 \%$ of TR-Cu for 67 samples (unpublished results). Porewater copper concentrations (PW-Cu) increased with increasing spiked-copper concentrations, and very high PW-Cu (6 $\pm 0.9 \mathrm{mg} / \mathrm{L})$ was measured for the $1000 \mathrm{mg} \mathrm{Cu} / \mathrm{kg}$ sandy treatment. The siltysand and sand PW-Cu concentrations were markedly greater in the $2^{\text {nd }}$ series $(0,100,200$, $400)$ than in the $1^{\text {st }}$ series $(0,200,1000)$ (Table 1$)$. This is most likely related to the $\mathrm{Cu}$ released from the copper-based paints over the 8 months, which would have been removed more effectively from the silty-sediment porewaters than the silty-sand and sand due to the higher concentrations of TOC and finer particles. The time-averaged dissolved copper concentrations in the overlying water $(\mathrm{OW}-\mathrm{Cu})$ also increased with increasing spiked-copper concentration. However, the $1^{\text {st }}$ and $2^{\text {nd }}$ silty-sand series did not display anomalously high values, as observed for $\mathrm{PW}-\mathrm{Cu}$.

Copper profiles in sediments by diffusive gradients in thin films (DGT). The principal characteristics of the DGT-Cu flux depth profiles on days 8 and 15 for the three sediment types (Figure 1) were: (i) peaks at the sediment-water interface (SWI), (ii) increased DGTinduced copper flux with increasing spiked-copper concentration, and (iii) lower DGTinduced copper flux in more silty sediments ( sand $>$ silty-sand $>$ silt). The peak in the DGTinduced copper flux near to the SWI is consistent with previous studies ${ }^{9}$ and has generally been attributed to its release from organic matter as it is oxidised. ${ }^{45,46}$ Depth profiles of Fe and $\mathrm{Mn}$ in the pore water were not obtained for the present study. However subsequent experiments using sediments with similar properties to the silty-sand that had been spiked with a copper mineral phase (unpublished results) indicated that the expected porewater Fe and $\mathrm{Mn}$ profiles were established rapidly after sediment disturbance (from collection and spiking) and 1 month equilibration (See Figure S1, Supporting Information). The mobilisation of copper through the reductive dissolution of Fe and Mn oxyhydroxide phases near the SWI is likely to be a major process influencing the copper fluxes. ${ }^{19}$ The very slow rate of copper release to the pore water and overlying water in the siltier sediments was consistent with the greater concentrations of TOC and fine particles, which provide copperbinding sites, in the sediments. ${ }^{12,35}$

Several anomalies existed in the DGT-Cu flux profiles for the $2^{\text {nd }}$ deployment (Figure 1f). 
exhibited unexpectedly high copper mobilisation in the deeper sediments. For the 100 and $200 \mathrm{mg} \mathrm{Cu} / \mathrm{kg}$ sand treatments and 200 and $400 \mathrm{mg} \mathrm{Cu} / \mathrm{kg}$ silty-sand treatments, the position of the DGT-Cu flux peaks was below the SWI. We believe that burrowing, deposit-feeding activity, and mortality of the bivalves was responsible for several of these observations. The movement of sediments by the bivalves may both increase the flux of copper at the $\mathrm{SWI}^{34,36}$ and deplete PW-Cu concentrations in the surface, thereby causing the DGT-Cu flux peak to become located at greater depth within the oxic/sub-oxic zone of the sediments. Bivalve mortalities (\% initial) were less than 5\% in controls, but $34 \%$ and $79 \%$ in 100 and $200 \mathrm{mg} / \mathrm{kg}$ sandy treatments, respectively, and 30\% and 50\% in 200 and $400 \mathrm{mg} / \mathrm{kg}$ silty-sand treatments, respectively. It is likely that significant mortality occurred within the early stages of the copper exposure ${ }^{47}$, and the decomposition of the organisms will have increased the availability of labile organic matter and stimulated microbial activity near the dead organisms. These processes may have also increased copper mobilisation from particulate organic phases, or decreased copper mobilisation through production of sulfide and formation of coppersulfide phases. ${ }^{10,12}$ No vertical movement in the DGT-Cu flux peak for the silty treatments was consistent with low toxicity and the low DGT-induced fluxes of PW-Cu in these sediments. As the anomalies were not present during the $1^{\text {st }}$ DGT deployments, the changes within the sediments that caused the new observations may have taken many days to occur. The reason for the highly elevated DGT-Cu flux in the $50 \mathrm{mg} \mathrm{Cu} / \mathrm{kg}$ sand treatment is not fully understood, however, Sochaczewski et al. ${ }^{4}$ found that DGT maxima could arise from a microniche - a local source with elevated concentration in the porewater, where the intensity of the maxima was related to the distance between the source and the DGT. In this study it is likely that the base of the DGT probe in the $50 \mathrm{mg} \mathrm{Cu} / \mathrm{kg}$ sand treatment was in close proximity to some copper-based paint particles.

Copper bioaccumulation by $\mathbf{T}$. deltoidalis. Due to the high level of lethality, tissue-Cu concentrations could not be determined for all $1000 \mathrm{mg} \mathrm{Cu} / \mathrm{kg}$ treatments, the sandy and siltysand treatments with $200 \mathrm{mg} \mathrm{Cu} / \mathrm{kg}$, and the silty-sand treatments with $400 \mathrm{mg} \mathrm{Cu} / \mathrm{kg}$ (Table 1). For each sediment type, positive relationships existed between tissue- $\mathrm{Cu}$ concentrations and the sediment copper concentrations (See Figures S2a\&b, Supporting Information). The properties of the sediments influenced the degree of copper bioaccumulation, with tissue- $\mathrm{Cu}$ concentrations increasing in the order sandy $>$ silty-sand $>$ silty when compared based on total recoverable $\mathrm{Cu}$ or dilute acid-extractable $\mathrm{Cu}$ concentrations. A number of studies have demonstrated the importance of sediment properties in influencing the partitioning of metals 
between the porewaters and sediment phases, ${ }^{25,26,28,48}$ and the influence of these two major exposure routes on the bioaccumulation of metals like copper. ${ }^{27,36,49}$

For each sediment type, linear relationships existed between tissue- $\mathrm{Cu}$ and the timeaveraged OW-Cu concentration $\left(\mathrm{r}^{2}=0.96\right.$ for combined data, Figure S2c). Consistent with dissolved copper in the overlying water being the predominant exposure pathway for $T$. deltoidalis, ${ }^{36,37}$ these relationships appeared to be largely independent of sediment type. While this bivalve is recognised as being a deposit feeder and accumulated copper from both dissolved and particulate exposure routes ${ }^{50}$, previous studies have found that copper accumulation is mostly attributed to exposure from the overlying water. ${ }^{37}$ The peak DGT-Cu flux, which occurred near the SWI, also provided strong relationships $\left(r^{2}=87\right.$ for combined data) with tissue-Cu concentrations in T. deltoidalis. Consistent with the observations by Roulier et al. ${ }^{30}$, the DGT-Cu concentration provided a better method for predicting copper bioaccumulation than the total copper measurements, i.e. it was less influenced by sediment properties.

Copper lethality to T. deltoidalis. The lethality of the sediments increased with copper concentrations and increased in the order sandy $>$ silty-sand $>$ silty (Figure 2). Dissolved ammonia concentrations were less than $5 \mathrm{mg} / \mathrm{L}$, which is well below the level known to effect T. deltoidalis. ${ }^{37}$ Consistent with copper bioaccumulation results, copper concentrationresponse models could be created based on the TR-Cu or AE-Cu concentrations for the individual sediments (Figures 2a,b), and also based on OW-Cu for the three sediment collectively (Figure 2c). There also appeared to be a useful relationship between survival and the tissue- $\mathrm{Cu}$ concentrations in T. deltoidalis (Figure 2d), however, because tissue- $\mathrm{Cu}$ concentrations were not determined for organisms that had died, inadequate data exists for the higher exposure concentrations.

Five different measures of copper exposure were used to calculate lethal copper concentrations (LC50, LC20, and LC10) for the 30-day exposures of T. deltoidalis: TR-Cu and $\mathrm{AE}-\mathrm{Cu}$ calculations used the separate sand, silty-sand and silt treatments, and $\mathrm{OW}-\mathrm{Cu}$, Tissue-Cu and DGT-Cu flux at the SWI used the combined data from all treatments (See Table S1, Supporting Information). As indicated in Figures 2a and b, the LC50 values (concentration causing 50\% lethality) increased in the order sand $<$ silty-sand $<$ silt, when calculated based on TR-Cu and AE-Cu concentrations. While neither TR-Cu nor AE-Cu provided a suitable representation of the bioavailable copper concentration, the $\mathrm{OW}-\mathrm{Cu}$ concentrations were useful for describing the toxicity in all the sediments. LC50 and LC10 
values of 27 (25-30) and 18 (13-26) $\mu \mathrm{g} \mathrm{OW-Cu/L}$ were calculated (Table S1). These results are consistent with the LC50 value of $33 \pm 1 \mu \mathrm{g} / \mathrm{L}$ determined by Strom et al. ${ }^{35}$ for copperspiked sediment with a range of properties.

The use of tissue concentrations to express the toxicity of metals is usually more useful for non-essential metals like $\mathrm{Cd}, \mathrm{Hg}, \mathrm{Pb}$, than essential metals like $\mathrm{Cu}$ and $\mathrm{Zn}$. $^{12,49,51}$ However, when the history of the metal exposure is controlled and known, tissue metal concentrations provide both direct evidence of exposure and metal bioavailability to the organisms and also useful expressions for toxicity for essential metals such as copper. ${ }^{48}$ For the 30-day laboratory exposures, owing to the rapid assimilation, the copper accumulation can be treated as metabolically bioavailable, ${ }^{27,28}$ and was used to calculate an LC10 for tissue-Cu of $500 \mathrm{mg} / \mathrm{kg}$ (dry weight) (Table S1).

A strong concentration-response relationship was also observed when the peak DGTinduced copper flux at the SWI (Figure 1) was used as a measure of the copper exposure concentration to T. deltoidalis (Figure 2e). Based on the DGT-Cu flux at the SWI, LC50 and LC10 values of 31 (24-42) and $15(6-35) \mu \mathrm{g} \mathrm{Cu} / \mathrm{m}^{2} / \mathrm{h}$ were calculated using all the data (Table S1). This relationship has a high degree of environmental significance in terms of the use of DGT for quantifying the risk posed by metal contaminated sediments. Many regulatory frameworks for sediment quality assessment incorporate procedures for determining a contaminants' bioavailability. ${ }^{52,53}$ However, while metal bioavailability is frequently assessed when the total concentration exceeds the sediment quality guideline value, there are many inadequacies with the methods currently utilised. ${ }^{12}$ Pore water metal analyses provide non time-integrated 'snap-shots' that are unlikely to reflect the actual exposure for many benthic organisms. ${ }^{12,54}$ It is generally not practical to make multiple field measurements of dissolved metal concentrations, which would allow time-averaged exposures to be accurately assessed.

343 Furthermore, there are numerous artifacts that make porewater analyses problematic in both oxic/sub-oxic and sulfidic sediments. ${ }^{19,55,56}$ The much used relationships between acid-volatile sulfide (AVS) and simultaneously extractable metals (SEM) $)^{57}$ can over-emphasise the importance of metal-sulfide binding, as the sediment-microenvironments surrounding many benthic organisms are oxic/sub-oxic either owing to the proximity to the SWI or due to irrigation of burrows with oxygenated waters. ${ }^{12,17,42}$ Consequently, porewater or AVS-SEM measurements may not always provide adequate information on metal bioavailability. While metal concentrations in organism tissues provide a direct measure of exposure, when organisms are collected from the field their exposure history is not usually known and a significant fraction of the accumulated metal is likely to have been converted to forms that are 
not metabolically available. ${ }^{49,58}$ This limits the use of lethal body concentration approach for assessing metal bioavailability. ${ }^{12,59}$

The DGT-Cu flux - bioaccumulation - toxicity relationships shown in Figure 2 demonstrate that DGT-induced metal flux measurements provide a very useful measure of metal bioavailability in sediments with varying properties. We believe the time-integrated metal fluxes derived from laboratory or field deployments of the relatively simple DGT device may provide a more reliable measure of metal bioavailability than porewater and AVSSEM analyses in many sediments. While, in some respects the accumulation of metals by the DGT probe simulates the bioaccumulation in sedentary benthic organism, the method does not directly assess metal bioavailability arising from dietary exposure (i.e. ingestion of particles). It has yet to be determined whether the DGT-induced metal flux may also provide useful information on the lability of metals on ingested particles. Although the limitations of using the DGT technique for measuring metal fluxes from sediments requires further assessment, we expect the technique will become more frequently used for assessing the bioavailability and potential ecotoxicological effects of metals in sediments.

Bioavailability of $\mathbf{C u}(\mathbf{I})$ oxide-based paints in sediments. The source of bioavailable copper in the tested sediments was copper-based antifouling paint particles and was chosen because of the increasing use by marine industries and concerns about the effects to biota within sediments contaminated with these materials. ${ }^{31}$ The release of copper from the paint particles to the pore water and overlying seawater, along with the bioaccumulation by the bivalves confirmed the presence of bioavailable copper in sediments. In the present study, the measurements of dilute acid-extractable copper provided no obvious advantage of total copper measurements for predicting the bioavailability of copper in the three sediments. This observation may be due, in part, to the use of sediments that were all artificially coppercontaminated and equilibrated for the same duration before testing, i.e. the partitioning between TR-Cu and AE-Cu forms was the similar for all sediments. For naturally contaminated sediments, which form over longer duration, dilute acid-extractable metal measurements and analyses of metal concentrations of the fine sediment fraction are frequently demonstrated to provide a better measure of metal bioavailability than analyses of total metal concentrations. ${ }^{12,60}$ Both the TR-Cu and AE-Cu measurements indicted that the bioavailability of the copper was significantly lower in the more silty sediments.

The toxicity to T. deltoidalis in the laboratory tests indicates copper-based paint contamination may cause significant effects to benthic organisms (Figure 2). However, as the 
majority of the copper exposure to T. deltoidalis was from the overlying water compartment, the same paint-contaminated sediments may not cause this degree of toxicity if assessed in situ, i.e. when situated with a deep water column. ${ }^{61}$ The copper extractability from the paintspiked sediments was also significantly greater than we have found for field-collected sediments contaminated with copper-based antifouling paints, and this may also contribute to an overestimation of the bioavailability compared to paint-contaminated sediments in the field.

For T. deltoidalis a large portion of the copper exposure was from the overlying water compartment $^{37}$, which was controlled by the DGT-Cu flux from the sediments in these laboratory tests. In a field location the in situ copper exposure and toxicity of the same paintcontaminated sediments would be lower due to the greater dilution of the released copper within the larger water column. ${ }^{61}$ For organisms that receive a greater exposure from the sediment pore waters, or may ingest fine paint particles within the sediments ${ }^{62}$, the in situ exposure may be more important.

\section{Acknowledgements}

401 Ian Hamilton and David Spadaro are thanked for assisting with collection and handling of bivalves and undertaking the bioassays. Robert Jung is thanked for assisting with paint and bivalve sample analyses.

\section{Supporting Information}

405 Supporting Information includes further information on the preparation of the DGT probes, profiles of porewater $\mathrm{Mn}$ and Fe concentrations, and relationships between copper bioaccumulation and a table lethal copper concentrations for the bivalve is provided for each of the different copper exposures. This information is available free of charge via the internet at http://pubs.acs.org/

\section{References}

411 1. Davison, W.; Zhang, H., In-situ speciation measurements of trace components in natural-waters 412 using thin-films gels. Nature 1994, 367, 546-548.

413 2. Zhang, H.; Davison, W.; Miller, S.; Tych, W. In situ high resolution measurements of fluxes of Ni, $414 \mathrm{Cu}, \mathrm{Fe}$, and $\mathrm{Mn}$ and concentrations of $\mathrm{Zn}$ and $\mathrm{Cd}$ in porewaters by DGT. Geochim. Cosmochim. Acta 415 1995, 59, 4181-4192.

416 3. DGT Research Ltd. Practical Guide for Using DGT for Metals in Waters Website; 417 http://www.dgtresearch.com/

418 4. Sochaczewski, Ł.; Davison, W.; Zhang, H.; Tych, W. Understanding small-scale features in DGT 419 measurements in sediments. Environ. Chem. 2009, 6, 477-485.

420 5. Harper, M. P.; Davison, W.; Zhang, H.; Tych, W. Kinetics of metal exchange between solids and 421 solutions in sediments and soils interpreted from DGT measured fluxes. Geochim. Cosmochim. Acta 1998, 62, 2757-2770. 
6. Stockdale, A.; Davison, W.; Zhang, H.; Hamilton-Taylor, J. The association of cobalt with iron and manganese (oxyhydr)oxides in marine sediment. Aquat. Geochem. 2010, 16, 575-585.

7. Zhang, H.; Davison, W.; Mortimer, R. J. G.; Krom, M. D.; Hayes, P. J.; Davies, I. M. Localised remobilization of metals in a marine sediment. Sci. Tot. Environ. 2002, 296, $175-187$.

8. Naylor, C.; Davison, W.; Motelica-Heino, M.; Van Den Berg, G. A.; Van Der Heijdt, L. M. Simultaneous release of sulfide with $\mathrm{Fe}, \mathrm{Mn}, \mathrm{Ni}$ and $\mathrm{Zn}$ in marine harbour sediment measured using a combined metal/sulfide DGT probe. Sci. Tot. Environ. 2004, 328, 275-286.

9. Tankere-Muller, S.; Zhang, H.; Davison, W.; Finke, N.; Larsen, O.; Stahl, H.; Glud, R. N..Fine scale remobilisation of $\mathrm{Fe}, \mathrm{Mn}, \mathrm{Co}, \mathrm{Ni}, \mathrm{Cu}$ and $\mathrm{Cd}$ in contaminated marine sediment. Mar. Chem. 2006, 106, 192-207.

10. Stockdale, A.; Davison, W.; Zhang, H. Formation of iron sulfide at faecal pellets and other microniches within suboxic surface sediment. Geochim. Cosmochim. Acta 2010, 74, 2665-2676.

11. Chapman, P. M.; Wang, F. Y.; Janssen, C.; Persoone, G.; Allen, H. E. Ecotoxicology of metals in aquatic sediments: binding and release, bioavailability, risk assessment, and remediation. Can. J. Fisheries Aquat. Sci. 1998, 55, 2221-2243.

12. Simpson, S. L.; Batley, G. E. Predicting metal toxicity in sediments: A critique of current approaches. Integr. Environ. Assessment Manag. 2007, 3, 18-31.

13. Wang, W. X.; Yan, Q. L.; Fan, W. H.; Xu, Y. Bioavailability of sedimentary metals from a contaminated bay. Mar. Ecol.-Prog. Ser. 2002, 240, 27-38.

14. Amiard, J. C.; Amiard-Triquet, C.; Barka, S.; Pellerin, J.; Rainbow, P. S. Metallothioneins in aquatic invertebrates: their role in metal detoxification and their use as biomarkers. Aquat. Toxicol. 2006, 76, 160-202.

15. Lee, B. G.; Griscom, S. B.; Lee, J. S.; Choi, H. J.; Koh, C. H.; Luoma, S. N.; Fisher, N. S. Influences of dietary uptake and reactive sulfides on metal bioavailability from aquatic sediments. Science, 2000, 287, 282-284.

16. Griscom, S. B.; Fisher, N. S. Uptake of dissolved Ag, Cd, and Co by the clam, Macoma balthica: Relative importance of overlying water, oxic pore water, and burrow water. Environ. Sci. Technol. 2002, 36, 2471-2478.

17. Simpson, S. L.; Ward, D.; Strom, D.; Jolley, D. F. Oxidation of acid-volatile sulfide in surface sediments increases the release and toxicity of copper to the benthic amphipod Melita plumulosa. Chemosphere 2012, 88, 953-961.

18. Ciutat, A.; Boudou, A. Bioturbation effects on cadmium and zinc transfers from a contaminated sediment and on metal bioavailability to benthic bivalves. Environ. Toxicol. Chem. 2003, 22, 1574 1581.

19. Simpson, S. L.; Batley, G. E. Disturbances to metal partitioning during toxicity testing Fe(II)-rich estuarine pore waters and whole-sediments. Environ. Toxicol. Chem. 2003, 22, 424-432.

20. Zhang, H.; Davison, W. Direct in situ measurements of labile inorganic and organically bound metal species in synthetic solutions and natural waters using diffusive gradients in thin films. Anal. Chem. 2000, 72, 4447-4457.

21. van Leeuwen, H. P.; Town, R. M.; Buffle, J.; Cleven, R. F. Davison, W.; Puy, J.; van Riemsdijk, W. H.; Sigg, L. Dynamic speciation analysis and bioavailability of metals in aquatic systems. Environ. Sci. Technol. 2005 39, 8545-8556.

22. Tusseau-Vuillemin, M. H.; Gilbin, R.; Bakkaus, E.; Garric, J. Performance of diffusion gradient in thin films to evaluate the toxic fraction of copper to Daphnia magna. Environ. Toxicol. Chem. 2004, 23, 2154-2161.

23. Jordan M. A.; Teasdale, P. R.; Dunn, R. J. K.; Lee, S. Y. Modelling copper uptake by Saccostrea glomerata with diffusive gradients in a thin film measurements. Environ. Chem. 2008, 5, 274-280.

24. Schintu, M.; Durante, L.; Maccioni, A.; Meloni, P.; Degetto, S.; Contu, A. Measurement of environmental trace-metal levels in Mediterranean coastal areas with transplanted mussels and DGT techniques. Mar. Poll Bull. 2008, 57, 832-837. 
25. Besser, J. M.; Brumbaugh, W. G.; May, T. W.; Ingersoll, C. G. Effects of organic amendments on the toxicity and bioavailability of cadmium and copper in spiked formulated sediments. Environ. Toxicol. Chem. 2003, 22, 805-815.

26. Riba, I.; Del Valls, T. A.; Forja, J. M.; Gomes-Parra, A. The influence of pH and salinity on the toxicity of heavy metals in sediment to the estuarine clam Ruditapes philippinarum. Environ. Toxicol. Chem. 2004, 23, 1100-1107.

27. Simpson, S. L. An exposure-effect model for calculating copper effect concentrations in sediments with varying copper binding properties: A synthesis. Environ. Sci. Technol. 2005, 39, 7089-7096.

28. Rainbow, P. S. Trace metal bioaccumulation: models, metabolic availability and toxicity. Environ. Int. 2007, 33, 576-582.

29. Wegener, J.-W. M.; van den Berg, G. A.; Stroomberg, G. J.; van Velzen, M. J. M. The role of sediment-feeding oligochaete Tubifex on the availability of trace metals in sediment pore waters as determined by diffusive gradients in thin films (DGT). J. Soils Sed. 2002, 2, 71-76.

30. Roulier, J. L.; Tusseau-Vuillemin, M. H.; Coquery, M.; Geffard, O.; Garric, J. Measurement of dynamic mobilization of trace metals in sediments using DGT and comparison with bioaccumulation in Chironomus riparius: First results of an experimental study. Chemosphere 2008, 70, 925-932.

31. Turner, A. Marine pollution from antifouling paint particles. Mar. Pollut. Bull. 2010, 60, 159-171. 32. Spadaro, D. A.; Micevska, T.; Simpson, S. L. Effect of nutrition on toxicity of contaminants to the epibenthic amphipod, Melita plumulosa. Arch. Environ. Contam. Toxicol. 2008, 55, 593-602.

33. Simpson, S. L. A rapid screening method for acid-volatile sulfide in sediments. Environ. Toxicol. Chem. 2001, 20, 657-2661

34. Simpson, S. L.; Pryor, I. D.; Mewburn, B.; Batley, G. E.; Jolley, D. F. Considerations for capping metal-contaminated sediments in dynamic estuarine environments. Environ. Sci. Technol. 2002, 36, 3772-3778.

35. Strom, D.; Simpson, S. L.; Jolley, D. F.; Batley, G. E. Accounting for the influence of sediment particle size and organic carbon on toxicity of copper to benthic invertebrates in oxic/sub-oxic surface sediments. Environ. Toxicol. Chem. 2011, 30, 1599-1610.

36. Atkinson, C. A.; Jolley, D. F.; Simpson, S. L. Effect of overlying water pH, dissolved oxygen, salinity and sediment disturbances on metal release and sequestration from metal contaminated marine sediments. Chemosphere 2007, 69, 1428-1437.

37. King, C. K.; Dowse, M. C.; Simpson, S. L. Toxicity of metals to the bivalve Tellina deltoidalis and relationships between metal bioaccumulation and metal partitioning between seawater and marine sediments. Arch. Environ. Contam. Toxicol. 2010, 58, 657-665.

38. Simpson, S. L.; Angel, B. M.; Jolley, D.F. Metal equilibration in laboratory-contaminated (spiked) sediments used for the development whole-sediment toxicity tests. Chemosphere, 2004, 54, 597-609.

39. Børufsen Solberg, C.; Sæthre, L.; Julshamn, K. The effect of copper-treated net pens on farmed salmon (Salmo salar) and other marine organisms and sediments. Mar. Pollut. Bull. 2002, 45, 126132.

40. Hutchins, C.; Teasdale, P. R; Lee, S. Y.; Simpson, S. L. Influence of sediment metal-spiking procedures on copper bioavailability and toxicity in the estuarine bivalve Indoaustriella lamprelli. Environ Toxicol. Chem. 2009, 28, 1885-1892.

41. Garmo Ø. A, Davison, W. Zhang, H. Effects of binding of metals to the hydrogel and filter membrane on the accuracy of the diffusive gradients in thin films technique. Anal. Chem. 2008, 80, 9220-9225.

42. Kristensen, E. Organic matter diagenesis at the oxic/anoxic interface in coastal marine sediments, with emphasis on the role of burrowing animals. Hydrobiologia 2000, 426, 1-24.

43. Hempel. Safety Data Sheet for Hempanet 7150A. Hempel Pty Ltd (Australia), Laverton North. 2009. 
44. Yebra, D. M.; Kiil, S.; Dam-Johansen, K. Antifouling technology - past, present and future steps towards efficient and environmentally friendly antifouling coatings. Prog. Org. Coat., 2004, 50, 75104.

45. Klinkhammer, G. P.; Heggie, D. T.; Graham, D. W. Metal diagenesis in oxic marine sediments. Earth Planet. Sci. Lett. 1982, 61, 211-219.

46. Sawlan, J. J.; Murray, J. W. Trace metal remobilisation in the interstitial waters of red clay and hemipelagic marine sediments. Earth Planet. Sci. Lett. 1983, 64, 213-230.

47. Angel, B. M.; Simpson, S. L.; Jolley, D. F. Toxicity to Melita plumulosa from intermittent and continuous exposures to dissolved copper. Environ. Toxicol. Chem. 2010, 29, 2823-2830.

48. Simpson, S. L.; King, C. K. Exposure-pathway models explain causality in whole sediment toxicity tests. Environ. Sci. Technol. 2005, 39, 837-843.

49. Luoma S. N.; Rainbow, P. S. Metal Accumulation in Aquatic Environments. Science and Lateral Management. Cambridge University Press: Cambridge, U.K. 2008.

50. King, C. K.; Simpson, S. L.; Smith, S. V.; Stauber, J. L.; Batley, G. E. Short-term accumulation of $\mathrm{Cd}$ and $\mathrm{Cu}$ from water, sediment and algae by the amphipod Melita plumulosa and the bivalve Tellina deltoidalis. Mar. Ecol.-Prog. Ser. 2005, 287, 177-188.

51. Borgmann, U. Derivation of cause-effect based sediment quality guidelines. Can. J. Fish. Aquat. Sci. 2003, 60, 352-360.

52. Batley, G. E.; Simpson, S. L. Advancing Australia's sediment quality guidelines. Aust. J. Ecotoxicol. 2008, 14, 11-20.

53. Ahlf, W.; Drost, W.; Heise, S. Incorporation of metal bioavailability into regulatory frameworksmetal exposure in water and sediment. J. Soils Sed. 2009, 9, 411-419.

54. Hare, L.; Tessier, A.; Borgmann, U. Metal sources for freshwater invertebrates: Pertinence for risk assessment. Human Ecol. Risk Assess., 2003, 9, 779-793.

55. Simpson, S. L.; Apte, S. C.; Batley, G. E. Sample storage artifacts affecting the measurement of dissolved copper in sulfidic porewaters. Anal. Chem. 1998, 70, 4202-4205.

56. Carr, R. S.; Nipper, M. J., Eds. Porewater toxicity testing. Society of Environmental Toxicity and Chemistry (SETAC): Pensacola, Florida, 2003.

57. USEPA (US Environmental Protection Agency). Procedures for the derivation of equilibrium partitioning sediment benchmarks (ESBs) for the protection of benthic organisms: Metal mixtures (cadmium, copper, lead, nickel, silver, and zinc). EPA-600-R-02-011. Office of Research and Development: Washington, DC. 2005

58. Amiard, J. C.; Geffard, A.; Amiard-Triquet, C.; Crouzet, C. Relationship between the lability of sediment-bound metals $(\mathrm{Cd}, \mathrm{Cu}, \mathrm{Zn})$ and their bioaccumulation in benthic invertebrates. Estuar. Coastal Shelf Sci. 2007, 72, 511-521.

59. Adams, W. J.; Blust, R.; Borgmann, U.; Brix, K. V.; DeForest, D. K.; Green, A. S.; Meyer, J. S.; McGeer, J. C.; Paquin, P. R.; Rainbow, P. S.; Wood, C. M. Utility of tissue residues for predicting effects of metals on aquatic organisms. Integr. Environ. Assess. Manage. 2011, 7, 75-98.

60. Simpson, S. L.; Spadaro, D. A. Performance and sensitivity of rapid sublethal sediment toxicity tests with the amphipod Melita plumulosa and copepod Nitocra spinipes. Environ. Toxicol. Chem. 2011, 30, 2326-2334.

61. Mann, R. M.; Hyne, R. V.; Simandjuntak, D. L.; Simpson, S. L. A rapid amphipod reproduction test for sediment quality assessment: In-situ bioassays do not replicate laboratory bioassays. Environ. Toxicol. Chem. 2010, 29, 2566-2574.

62. Campana, O.; Spadaro, D. A.; Blasco, J.; Simpson, S. L. Sublethal effects of copper to benthic invertebrates explained by changes in sediment properties and dietary exposure. Environ. Sci. Technol. 2012, dx.doi.org/10.1021/es2045844. 
573 Table 1. Copper concentrations in sediments and waters and copper bioaccumulation by T. deltoidalis in 574 the $\mathrm{Cu}(\mathrm{I})$ oxide-paint spiked sediment types

\begin{tabular}{|c|c|c|c|c|c|c|c|c|c|c|c|}
\hline & & \multirow[t]{2}{*}{$\begin{array}{c}\text { Nominal } \\
\mathrm{mg} / \mathrm{kg}\end{array}$} & \multicolumn{2}{|c|}{$\begin{array}{l}\mathrm{TR}-\mathrm{Cu} \\
\mathrm{mg} / \mathrm{kg}\end{array}$} & \multicolumn{2}{|c|}{$\begin{array}{l}\mathrm{AE}-\mathrm{Cu} \\
\mathrm{mg} / \mathrm{kg}\end{array}$} & \multicolumn{2}{|c|}{$\begin{array}{c}\mathrm{PW}-\mathrm{Cu} \\
\mu \mathrm{g} / \mathrm{L}\end{array}$} & \multicolumn{2}{|c|}{$\begin{array}{c}\mathrm{OW}-\mathrm{Cu} \\
\mu \mathrm{g} / \mathrm{L}\end{array}$} & \multirow{2}{*}{ 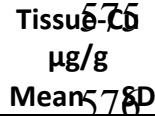 } \\
\hline & & & Mean & SD & Mean & SD & Mean & SD & Mean & SD & \\
\hline \multirow{7}{*}{ 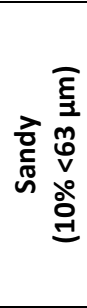 } & \multirow{7}{*}{$\frac{-1}{\tilde{c}}$} & $0^{a}$ & 5 & 2 & 3 & 1 & 4.4 & 11 & 2.6 & 3.1 & $86 \quad 28$ \\
\hline & & $200^{a}$ & 200 & 15 & 134 & 5 & 5.8 & 5 & 45 & 16 & ND 57 NדD \\
\hline & & $1000^{a}$ & 1000 & 75 & 690 & 130 & 6000 & 900 & 1450 & 300 & ND ND \\
\hline & & 0 & 5 & 2 & 3 & 1 & 3.7 & 2 & 1.6 & 1.2 & 1145782 \\
\hline & & 50 & 38 & 7 & 29 & 3 & 12.7 & 3 & 7.5 & 1.8 & 275 ND \\
\hline & & 100 & 109 & 8 & 60 & 9 & 17.2 & 5 & 14 & 3.3 & $31457 \mathrm{AD}$ \\
\hline & & 200 & 176 & 13 & 107 & 5 & 115 & 47 & 34 & 5.1 & 1370 ND \\
\hline \multirow{7}{*}{ 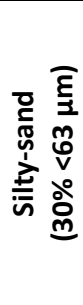 } & \multirow{3}{*}{$\stackrel{-1}{\stackrel{y}{\nu}}$} & $0^{a}$ & 10 & 4 & 7 & 2 & 0.2 & 3 & 1.1 & 1.5 & $8658 \theta^{9}$ \\
\hline & & $200^{a}$ & 200 & 15 & 134 & 15 & 2.4 & 2 & 19 & 6.5 & $677 \quad 58$ \\
\hline & & $1000^{a}$ & 1000 & 75 & 670 & 150 & 4.6 & 2 & 76 & 28 & ND 58ND \\
\hline & \multirow{4}{*}{ 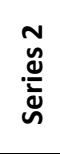 } & 0 & 12 & 1 & 11 & 7 & 0.5 & 0 & 1.7 & 2.5 & 154 \\
\hline & & 100 & 86 & 8 & 81 & 1 & 18.5 & 4 & 12 & 1.4 & $43158 \mathrm{QD}$ \\
\hline & & 200 & 159 & 8 & 128 & 16 & 35.4 & 6 & 23 & 5.2 & ND ND \\
\hline & & 400 & 315 & 17 & 212 & 73 & 62.1 & 21 & 26 & 5.4 & ND 58ỹ \\
\hline \multirow{7}{*}{ 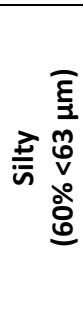 } & \multirow{4}{*}{$\frac{\vec{r}}{\tilde{y}}$} & $0^{a}$ & 30 & 10 & 20 & 4 & 0.3 & 1 & 0.9 & 0.8 & $\begin{array}{ll}85 & 11\end{array}$ \\
\hline & & $200^{a}$ & 200 & 15 & 134 & 15 & 7.2 & 3 & 15 & 6 & 4995840 \\
\hline & & $1000^{a}$ & 950 & 75 & 640 & 150 & 6.4 & 6 & 49 & 12 & ND \\
\hline & & 0 & 27 & 3 & 13 & 7 & 0.5 & 0 & 0.5 & 0.6 & 1345 \\
\hline & \multirow{3}{*}{$\stackrel{N}{\tilde{y}}$} & 100 & 143 & 39 & 96 & 11 & 5.3 & 6 & 1.7 & 1.1 & $194588^{4}$ \\
\hline & & 200 & 234 & 11 & 113 & 20 & 1.1 & 1 & 2 & 1 & 2765832 \\
\hline & & 400 & 426 & 91 & 250 & 77 & 3.9 & 3 & 7.7 & 2.2 & 414 \\
\hline
\end{tabular}

$\mathrm{TR}-\mathrm{Cu}=$ total recoverable copper $(\mathrm{n}=2)$. AE- $\mathrm{Cu}=$ dilute acid-extractable copper $(\mathrm{n}=2)$.

$590 \mathrm{ND}=$ not determined due to inadequate tissue mass due to poor survival.

$591 \mathrm{PW}-\mathrm{Cu}(\mathrm{n}=2$, at start and finish) and $\mathrm{OW}-\mathrm{Cu}(\mathrm{n}=10$, time average of samples approximately every 3 days $)$ are dissolved 592 copper in porewater and overlying water, respectively.

$593 \quad{ }^{a}$ First concentration series.

594

595

596 

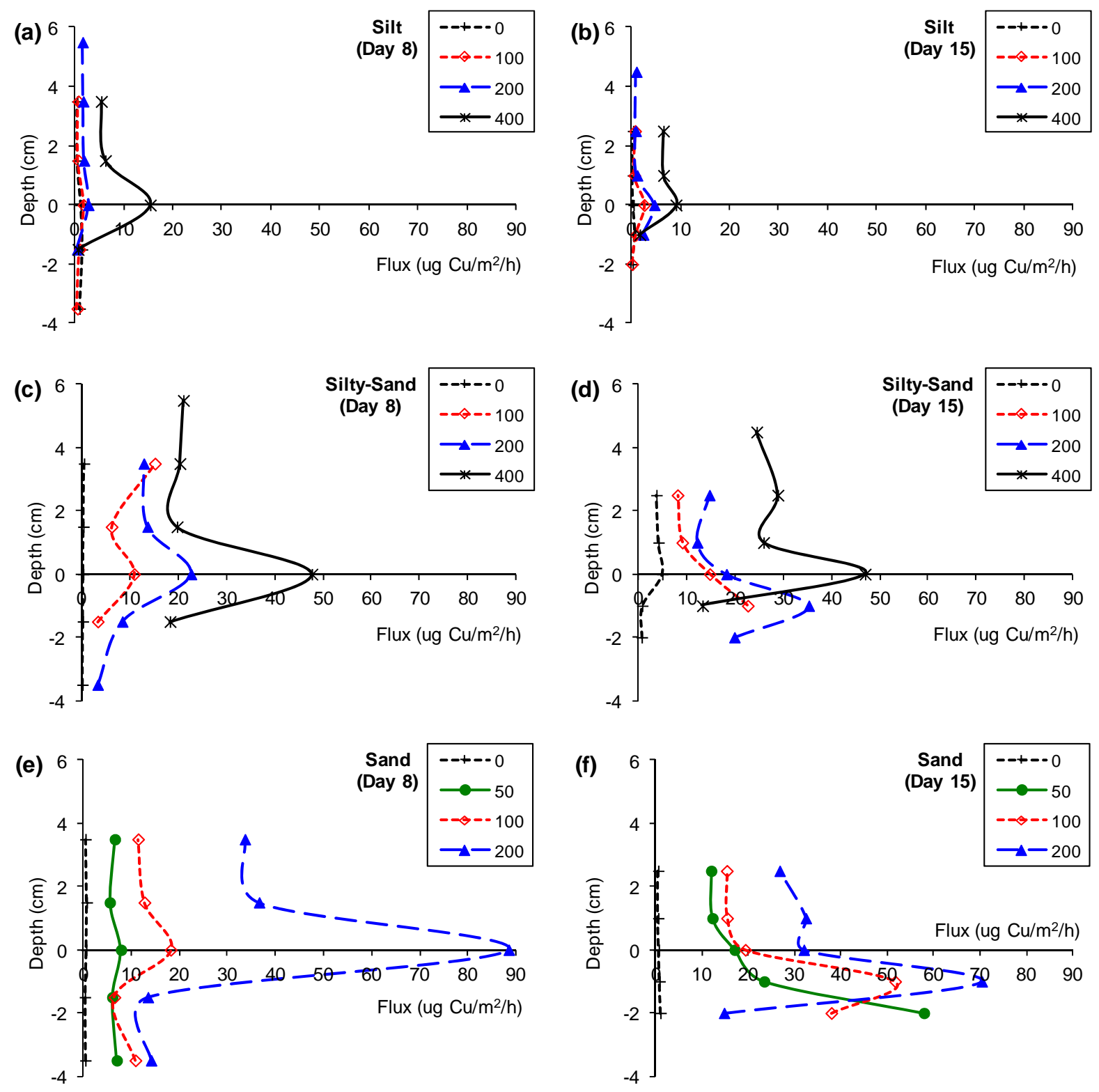

600 Figure 1. Depth profiles of the 24-h DGT copper flux on days 8 and 15 for the three copper 601 concentration series: $0,50,100,200 \mathrm{mg} \mathrm{Cu} / \mathrm{kg}$ for the sandy, and $0,100,200,400 \mathrm{mg} \mathrm{Cu} / \mathrm{kg}$ for the 602 silty-sand and silty series. Error bars have been omitted for clarity (Table S1 of Supplementary 603 Information). 

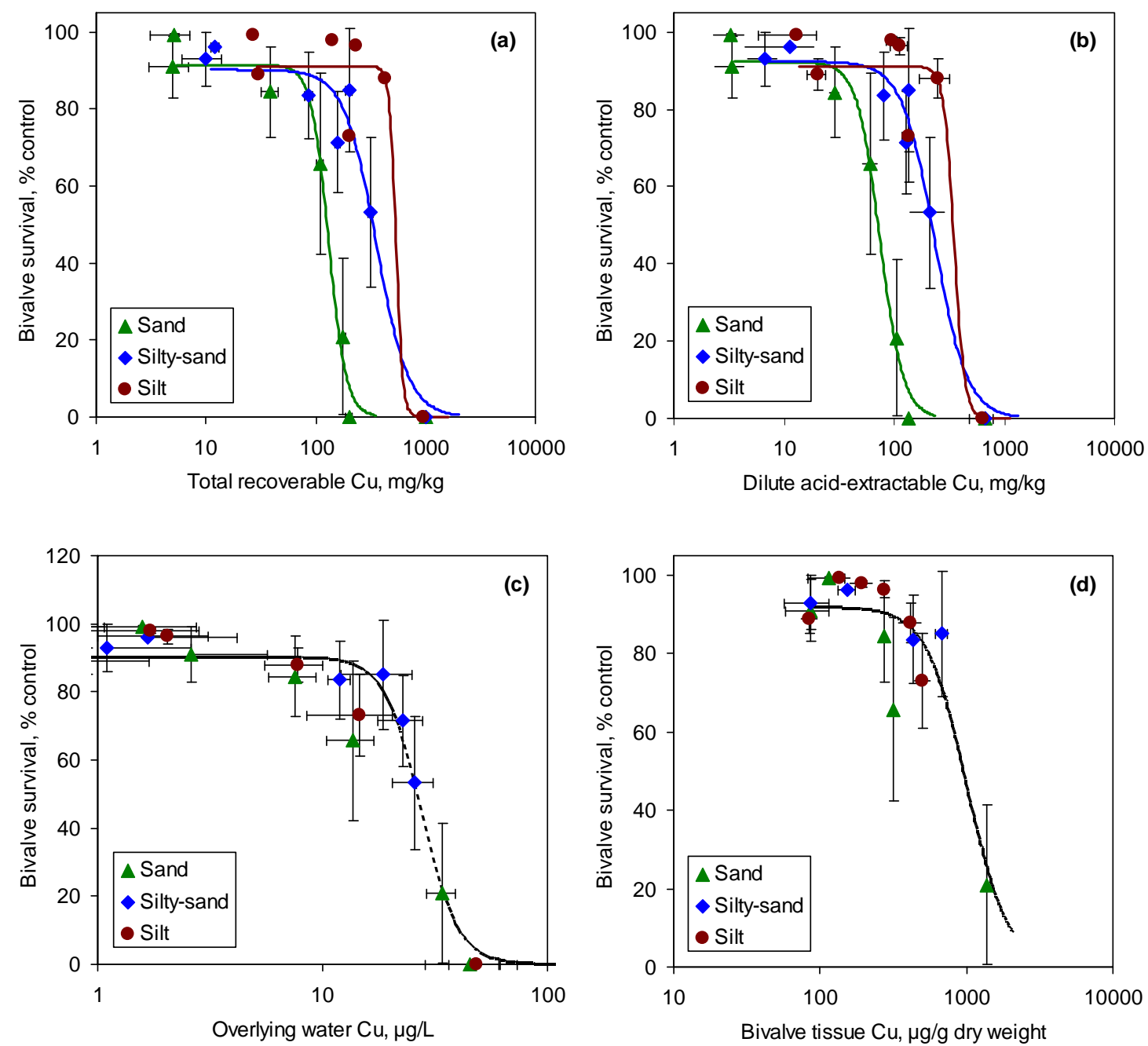

609

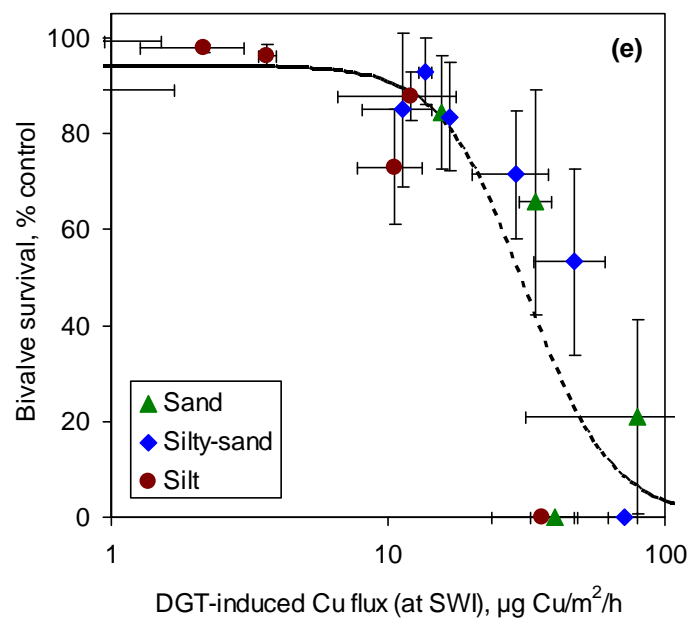

Figure 2. Relationships between survival of the bivalve, Tellina deltoidalis, and different copper exposures: (a) total recoverable copper, (b) dilute acid-extractable copper, (c) dissolved copper in overlying water, (d) bivalve tissue-Cu concentrations, and (e) peak DGTinduced $\mathrm{Cu}$ flux at the sediment water interface (DGT-Cu flux). Data presented for three sediment types for the different $\mathrm{Cu}$-spike concentrations (mean $\pm \mathrm{SD}, \mathrm{n}=2$ ). The lines represent log-logistic concentration response curves calculated for the three different sediment types for (a) and (b) and for the combined data for (c), (d) and (e). The LC50, LC20 and LC10 values for each relationship are provided in Table S1 of the Supporting Information. 
620

621

622

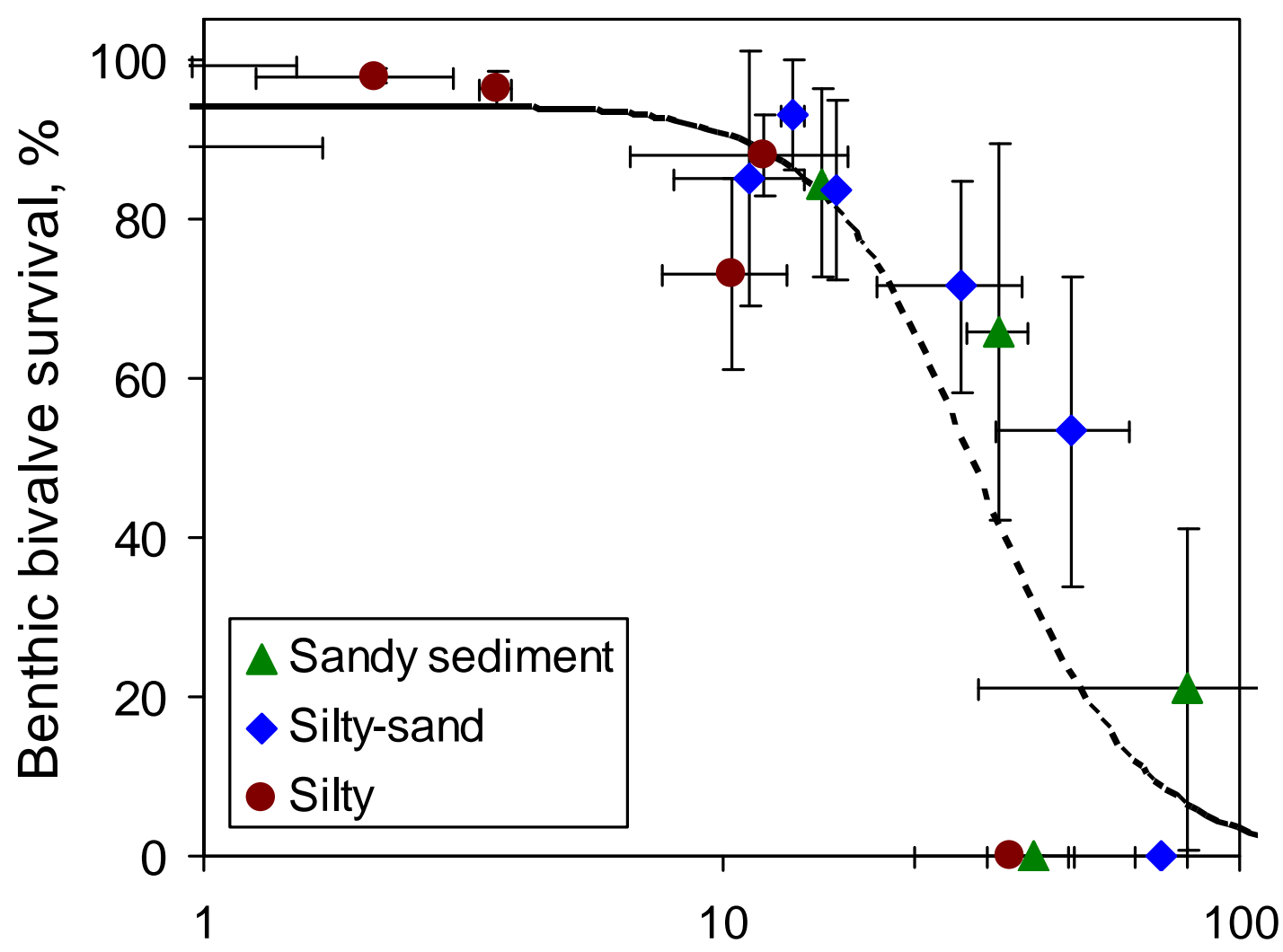

623 $\mu \mathrm{g} \mathrm{Cu} / \mathrm{m}^{2} / \mathrm{h}$

624

625 
DGT-INDUCED COPPER FLUX PREDICTS BIOACCUMULATION AND TOXICITY TO

Simpson, Stuart L. ${ }^{\dagger}$, Jolley, Dianne F. ${ }^{\ddagger}$, Yverneau, Héloïse, ${ }^{\dagger \cdot ¥}$, Cremazy, Anne, ${ }^{\dagger} \S$, Jarolimek, Chad V. ${ }^{\dagger}$, Price, Helen L. ${ }^{\ddagger}$

$\dagger$ Centre for Environmental Contaminants Research, CSIRO Land and Water, Locked Bag 2007, Kirrawee, NSW 2234, Australia

$¥$ Ecole Nationale Supérieure de Chimie de Montpellier - National Graduate School of Chemistry of Montpellier,

$637 \S$ Ecole Nationale Supérieure de Physique et Chimie de Bordeaux (ENSCPB), Pessac 33607, France.

$638+$ School of Chemistry, University of Wollongong, NSW 2522, Australia

639

* To whom correspondence may be addressed (stuart.simpson@,csiro.au)

S1 Methodology:

\section{S1.1 Preparation of diffusive gradients in thin films (DGT) probes}

Plastic DGT assemblies with open windows of $1.8 \times 15 \mathrm{~cm}$ and overall dimensions of $24 \times 4 \times 0.5 \mathrm{~cm}$ were purchased from DGT Research (Lancaster, UK). All glass and plasticware for DGT probes preparation were cleaned by soaking in detergent (commercial detergent diluted in tap water) for $24 \mathrm{~h}$, then in $10 \%(\mathrm{v} / \mathrm{v}) \mathrm{HNO}_{3}$ (70\%, AR grade, Ajax Finechem Pty Ltd) for $24 \mathrm{~h}$ and rinsed thoroughly with MQ water. All glass and plasticware for DGT probes analysis were cleaned by soaking in $10 \%(\mathrm{v} / \mathrm{v}) \mathrm{HNO}_{3}$ for $24 \mathrm{~h}$ and rinsed thoroughly with MQ water.

DGT gels were prepared from a stock solution comprising of $15 \%(\mathrm{w} / \mathrm{v})$ acrylamide ( $40 \%$ acrylamide solution, Electrophoresis Purity Reagent, Bio-Rad Laboratories) and 0.3\% (w/v) DGT cross-linker (2\% aqueous solution DGT Cross Linker, DGT Research, Lancaster, U.K.). The gel chemical polymerization for diffusive gels $(0.50 \mathrm{~mm}$-thick) was initiated by adding $75 \mu \mathrm{L}$ of $10 \%(\mathrm{w} / \mathrm{v})$ freshly made APS ( $98+\%$ ammonium persulfate, for analysis ACS, Acros Organics) to $10 \mathrm{~mL}$ of stock solution and catalysed by adding $25 \mu \mathrm{L}$ of TEMED (99\% N,N,N,N-tetramethylethylenediamine, Molecular Biology tested, Sigma). The solution was stirred for $3 \frac{1}{2}$ minutes, then immediately cast between a pair of glass plates separated by a $0.5 \mathrm{~mm}$ plastic spacer. The gel solution was left to polymerize for $1 \mathrm{~h}$ at $45^{\circ} \mathrm{C}$.

Wet Chelex resin was prepared by mixing $2 \mathrm{~g}$ of dry Chelex resin with $10 \mathrm{~mL}$ of MQ water, then allowing the resin to settle and withdrawing the overlying water with a pipette. Chelex gels $(0.25 \mathrm{~mm}$-thick) were prepared by adding $5 \mathrm{~mL}$ of stock solution to $2 \mathrm{~g}$ of wet chelating resin, then $25 \mu \mathrm{L}$ of initiator $(10 \%(\mathrm{w} / \mathrm{v})$ freshly made APS) and $7.5 \mu \mathrm{L}$ of catalyst (TEMED). The solution was mixed for 3 minutes, then immediately cast between a pair of glass plates separated by a $0.25 \mathrm{~mm}$ plastic spacer. The solution was then left to polymerize for $1 \mathrm{~h}$ at $45^{\circ} \mathrm{C}$.

The resulting diffusive and Chelex gels were removed from the glass plates and hydrated in Milli-Q water for $24 \mathrm{~h}$, replenishing the water three times to remove all unreacted chemicals. Diffusive gels were stored in 
$0.01 \mathrm{M} \mathrm{NaNO}_{3}$ (AR grade, Chem Supply) at room temperature and Chelex gels were stored in Milli-Q water in a

667 refrigerator at $4^{\circ} \mathrm{C}$ until use for probe construction. Gels were cut with a Teflon coated razor blade using a

668 plastic rectangular strip of the desired dimensions in order to fit in the DGT device. Acid-cleaned $0.45 \mu \mathrm{m}$ filter

669 membranes were cut and stored in MQ water. Probes were assembled by laying a wet filter membrane on the

670 base, overlaying a Chelex gel layer, then a diffusive gel layer and finally another wet filter membrane on the

671 DGT backing plates and closing the devices with the front window plates. Care was taken to ensure no air

672 bubbles were trapped within the layers. The DGT units were kept in sealed clean plastic bags containing few

673 drops of MQ water to avoid gel drying and stored in a refrigerator until deployment.

\section{S1.1 DGT probes deployment, retrieval and analysis}

675 To prevent the introduction of oxygen into the sediments during the deployment, DGT probes were

676 deoxygenated for $24 \mathrm{~h}$ prior to deployment by immersing them in a $0.05 \mathrm{M} \mathrm{NaCl}(>95.5 \%$, Sigma) solution

677 saturated with nitrogen gas (continually bubbling to remove the dissolved oxygen). DGT devices were

678 immediately gently inserted into the test beakers to a depth of $4 \mathrm{~cm}$ with care to ensure a good contact between

679 the sediment and the DGT membrane. After $24 \mathrm{~h}$ of deployment, DGT probes were gently removed from the

680 beakers and both sediment and overlying water levels were noted. Devices were immediately rinsed with MQ

681 water to remove all remaining sediment particles. Probes were put in clean plastic bags and kept in a cool room

$682\left(4^{\circ} \mathrm{C}\right)$ until disassembly.

683 DGT devices were disassembled (within 10 days of retrieval) and resin gel slices cut using a Teflon coated

684 blade to obtain the desired vertical profile: two $2-\mathrm{cm}$ slices in the overlying water, a one 1-cm slice at the

685 sediment-water interface (SWI) and one 2-cm slice in the sediment. Some of the slices from below the SWI had

686 sediment particles adhered to them which were removed by washing with MQ water. Each slice was weighed

687 and put into a 5-mL vial, then eluted with $1 \mathrm{~mL}$ of $1 \mathrm{M} \mathrm{HNO}_{3}$ for $16-24 \mathrm{~h}$ before analysis by ICP-MS.

688 Undeployed DGT probes were analysed as handling blanks and their copper concentrations were less than 5\% of

689 the lowest measured concentration.

690

691 
Table S1. Lethal copper concentrations for the bivalve, Tellina deltoidalis (Figure 2)

\begin{tabular}{|c|c|c|c|}
\hline & $\begin{array}{l}\text { TR-Cu, mg/kg } \\
\text { (Sand) }\end{array}$ & $\begin{array}{c}\text { TR-Cu, mg/kg } \\
\text { (Silty-sand) }\end{array}$ & $\begin{array}{c}\text { TR-Cu, mg/kg } \\
\text { (Silt) }\end{array}$ \\
\hline LC50 (95\% CL) & $130(110-156)$ & $355(244-518)$ & $530(---)$ \\
\hline LC20 (95\% CL) & $102(78-136)$ & $223(120-415)$ & $490(---)$ \\
\hline \multirow[t]{2}{*}{ LC10 $(95 \% \mathrm{CL})$} & $88(63-132)$ & $170(67-414)$ & $460(---)$ \\
\hline & $\begin{array}{l}\text { AE-Cu, mg/kg } \\
\text { (Sand) }\end{array}$ & $\begin{array}{l}\text { AE-Cu, mg/kg } \\
\text { (Silty-sand) }\end{array}$ & $\begin{array}{c}\text { AE-Cu, mg/kg } \\
\text { (Silt) }\end{array}$ \\
\hline LC50 (95\% CL) & $75(61-91)$ & $178(93-339)$ & $350(---)$ \\
\hline LC20 (95\% CL) & $54(39-77)$ & $87(35-224)$ & $300(---)$ \\
\hline \multirow[t]{2}{*}{ LC10 (95\% CL) } & $44(29-74)$ & $57(16-217)$ & $280(---)$ \\
\hline & $\begin{array}{c}\mathrm{OW}-\mathrm{Cu}, \mu \mathrm{g} / \mathrm{L} \\
\text { (All treatments) }\end{array}$ & $\begin{array}{l}\text { Tissue-Cu, } \mathrm{mg} / \mathrm{kg} \\
\text { (All treatments) }\end{array}$ & $\begin{array}{l}\text { DGT-Cu flux, ug Cu/m } / \mathrm{m}^{2} / \mathrm{h} \\
\text { (All treatments) }\end{array}$ \\
\hline LC50 (95\% CL) & $27(25-30)$ & $1000(770-1300)$ & $31(24-42)$ \\
\hline LC20 (95\% CL) & $21(17-27)$ & $650(380-1100)$ & $19(11-36)$ \\
\hline LC10 (95\% CL) & $18(13-26)$ & $500(230-1100)$ & $15(6-35)$ \\
\hline
\end{tabular}

693 LC50 $(95 \% \mathrm{CL})=$ concentration causing 50\% lethality (measured after 30 days).

694 LC20 and LC10 represent $20 \%$ and $10 \%$ effect concentrations, respectively.

$69595 \% \mathrm{CL}=95 \%$ confidence limit (--- = not possible to calculate $95 \% \mathrm{CL})$.

$696 \mathrm{TR}-\mathrm{Cu}=$ total recoverable copper concentration (aqua regia, $\mathrm{mg} / \mathrm{kg}$ ).

$697 \mathrm{AE}-\mathrm{Cu}=$ dilute acid-extractable copper concentration $(1-\mathrm{M} \mathrm{HCl}, \mathrm{mg} / \mathrm{kg})$

$698 \mathrm{OW}-\mathrm{Cu}=$ overlying water copper concentrations (30-day time averaged concentration, $\mu \mathrm{g} / \mathrm{L}$ )

699 Tissue- $\mathrm{Cu}=$ copper concentrations after 30 days in surviving bivalves $(\mathrm{mg} / \mathrm{kg}$, dry weight)

700 DGT-Cu flux $=$ Peak DGT-induced $\mathrm{Cu}$ flux at the sediment-water interface $\left(\mathrm{ug} \mathrm{Cu} / \mathrm{m}^{2} / \mathrm{h}\right)$

701 Effects thresholds for TR-Cu and AE-Cu were calculated separately for sand, silty-sand and silt treatments 

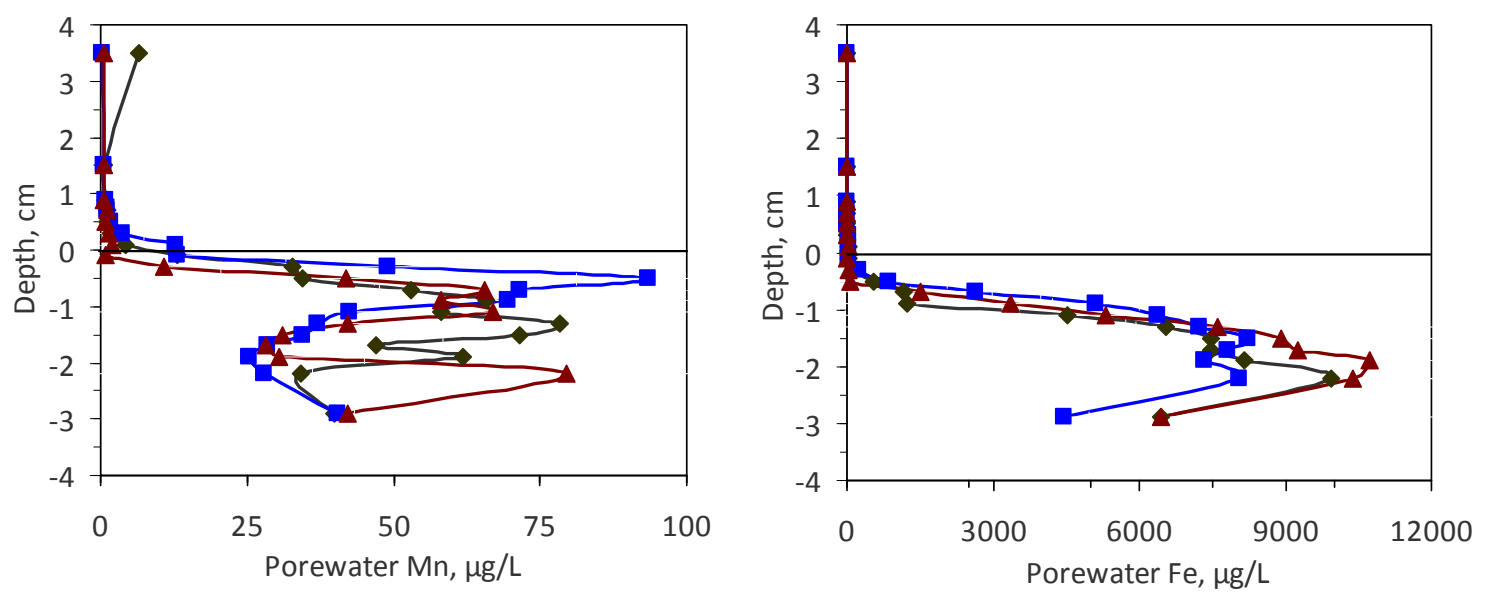

707 Figure S1. Porewater Mn and Fe concentrations within silty-sand that had been spiked with a copper mineral phase (unpublished results), confirming that the expected porewater Fe and $\mathrm{Mn}$ profiles develop following sediment disturbance and one month equilibration following spiking. The three porewater metal profiles $(\boldsymbol{\bullet}, \mathbf{\Delta})$ are from three DGTs from separate experiments. 

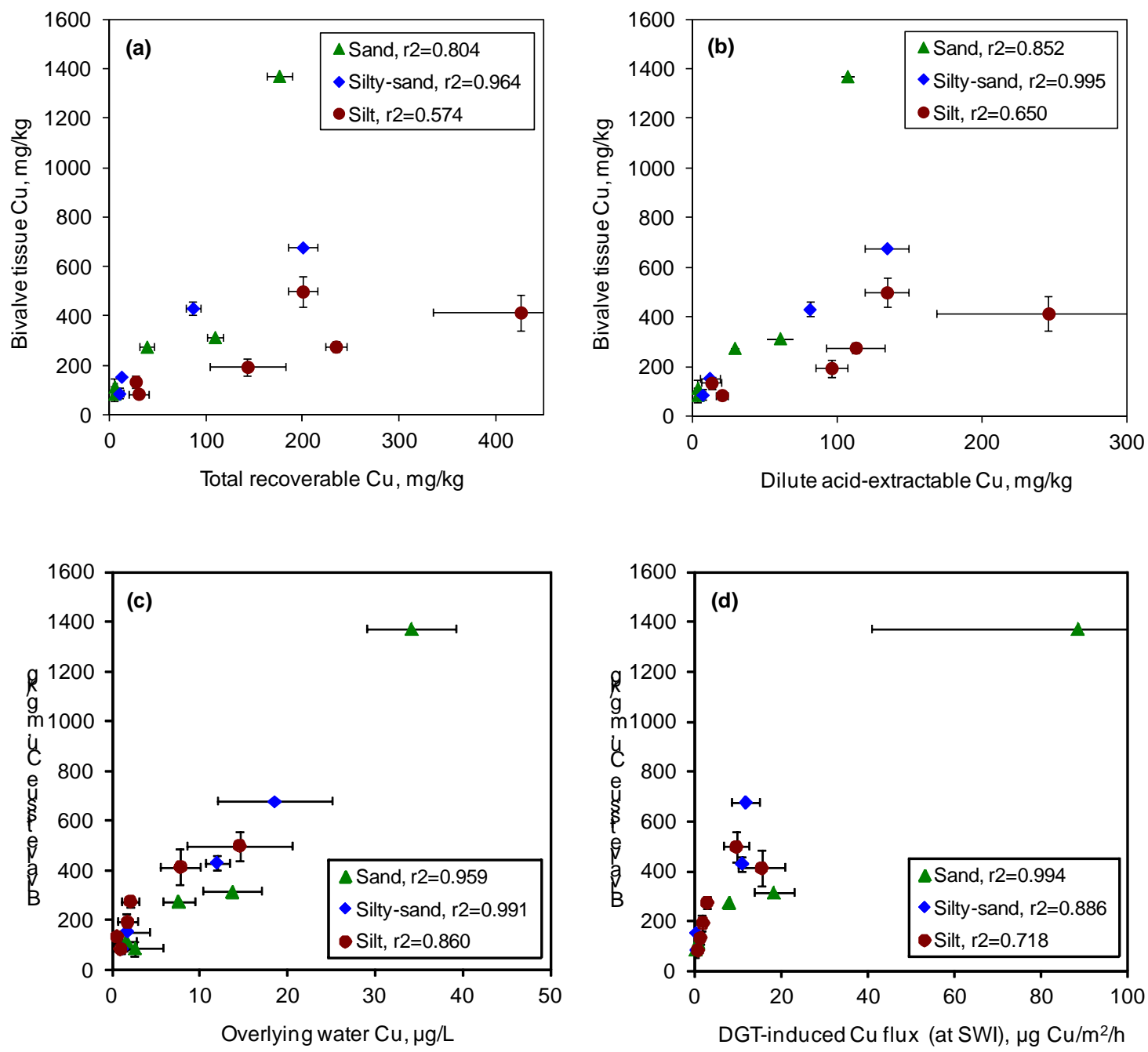

Figure S2. Relationships between copper bioaccumulation by bivalve, Tellina deltoidalis, and

716 different copper exposures: (a) total recoverable copper (TR-Cu), (b) dilute acid-extractable copper (AE-Cu), (c) dissolved copper in overlying water (OW-Cu, time averaged) and (d) peak

718 DGT-induced $\mathrm{Cu}$ flux at the sediment-water interface (DGT-Cu flux). Data presented for three

719 sediment types for the different $\mathrm{Cu}$-spike concentrations (mean $\pm \mathrm{SD}, \mathrm{n}=2$ ).

720 Correlations $\left(\mathrm{r}^{2}\right)$ between copper bioaccumulation by bivalve and copper concentrations for

721 each of the sediment types

\begin{tabular}{lcccc}
\hline Sediment type & (a) TR-Cu & (b) AE-Cu & (c) OW-Cu & (d) DGT flux \\
\hline Sand & 0.804 & 0.852 & 0.959 & 0.994 \\
Silty-sand & 0.964 & 0.995 & 0.991 & 0.886 \\
Silt & 0.574 & 0.650 & 0.860 & 0.718 \\
\hline Combined data & NA & NA & 0.962 & 0.865 \\
\hline
\end{tabular}

